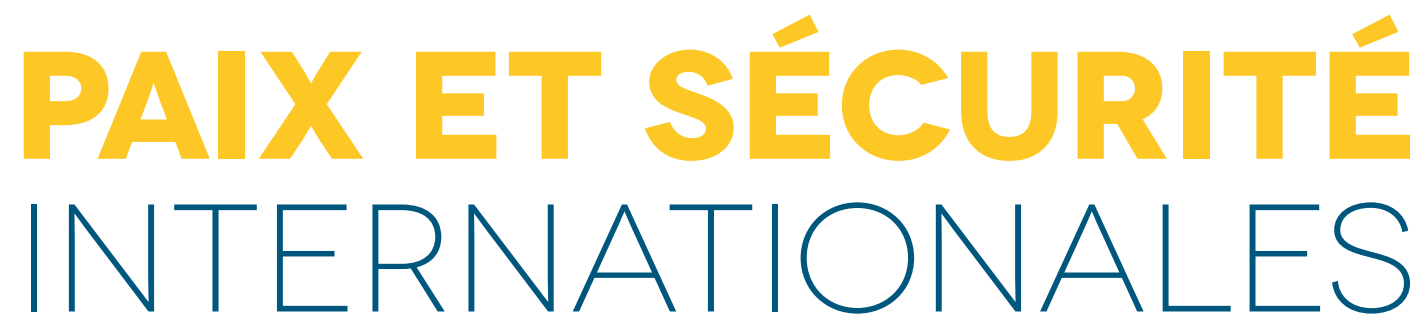

\title{
01
}

2013

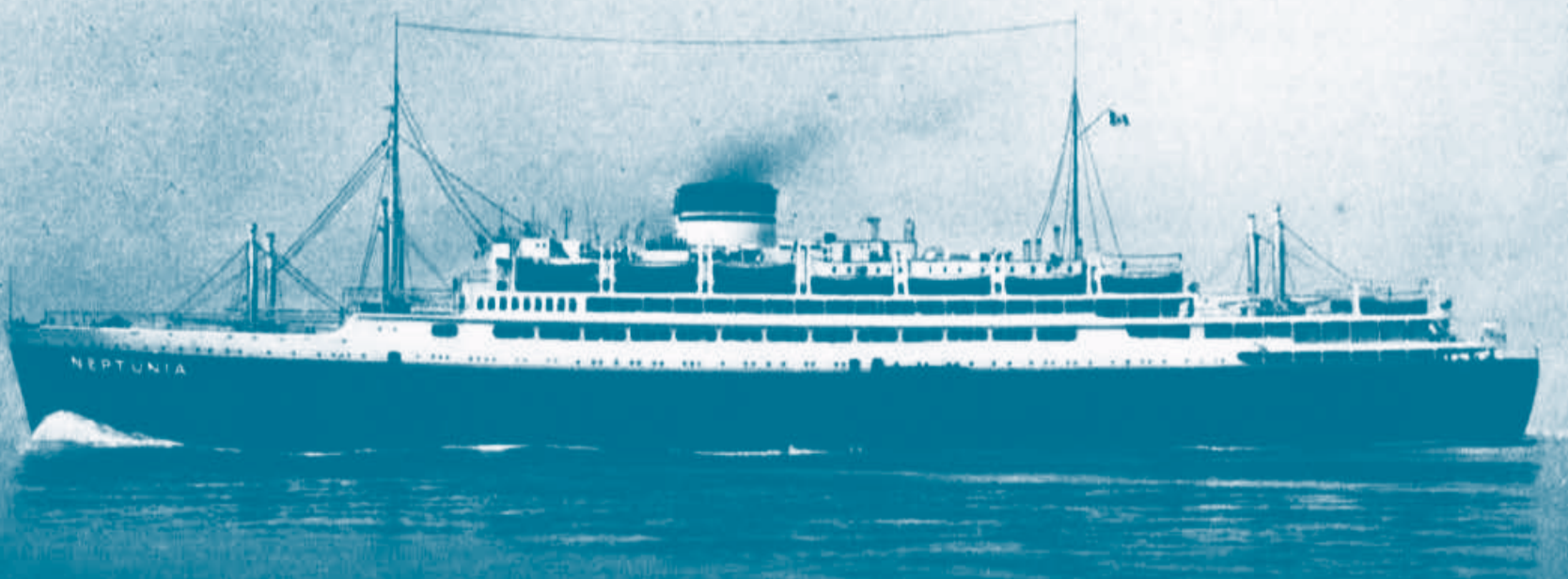

REVUE MAROCO-ESPAGNOLE DE DROIT INTERNATIONAL ET RELATIONS INTERNATIONALES

(NOUVELLE ÉPOQUE) 


\title{
KIDNAPPINGS AS A TERRORIST INSTRUMENT OF AQIM AND THE MUJAO
}

Carlos Echeverría Jesus ${ }^{3}$

\author{
I.- INTRODUCTION. II.- THE GSPC AND AQIM: THE CENTRAL \\ ACTORS. III.- MOVEMENT FOR ONENESS AND JIHAD IN WEST \\ AFRICA (MUJAO) AND THE NIGERIANS BOKO HARAM AND \\ ANSARU, AS AQIM'S EMULATORS. IV.- CONCLUSIONS.
}

\section{KIDNAPPINGS AS A TERRORIST INSTRUMENT OF AQIM AND THE MUJAO}

\begin{abstract}
This article updates to the Spring of 2013 the kidnappings implemented by a number of Salafist-Jihadist groups acting in the Maghreb, the Sahel, and Nigeria, providing analysis. Since then, a number of hostages have been released and other foreigners have been kidnapped, but the key-issues defining the terrorist groups' strategies remain. The threat is always there, and their most negative consequences (payment of ransoms and release of Jihadist-Salafist prisoners, among others) do remain as well.

KEYWORDS: AQIM; Algeria; Ansaru; Boko Haram; In Amenas; Jihadist-Salafist terrorism; kidnappings; Libya; Maghreb; Mali; MUJAO; Niger; Nigeria; ramsons; Sahel; SGPC (GSPC, in its more frequent French acronym); Tunisia.
\end{abstract}

\section{LOS SECUESTROS COMO INSTRUMENTO TERRORISTA DE AQMI Y DEL MUYAO}

RESUMEN: Este artículo analiza el estado de la cuestión en la primavera de 2013 de los secuestros realizados por grupos yihadistas salafistas en el Magreb, el Sahel y Nigeria. Desde entonces algunos rehenes han sido liberados y otros secuestrados, pero los elementos claves relacionados con la estrategia de los grupos terroristas siguen siendo los mismos. La amenaza perdura en esta dimensión, y las lacras que produce - en forma de pagos de rescates o de liberación de yihadistas presos, entre otras - también.

PALABRAS CLAVE: AQMI; Ansaru; Argelia; Boko Haram; GSPC; In Amenas; Libia; Magreb; Malí; MUYAO; Níger; Nigeria; rescates; Sahel; secuestros; terrorismo yihadista salafista; Túnez.

\section{LES ENLEVEMENTS, UN INSTRUMENT TERRORISTE DE L' AQMI ET DU MUJAO}

RESUME : Cet article met au jour dans le printemps 2013 et analyse les enlevements des hotages par les groupes Jihadistes-Salafistes actifs au Maghreb, au Sahel et dans le Nigéria. Suite à çe moment, quelques hotages ont été liberés et des autres kidnappés, mais les clefs pour definer les strategies des groups terroristes restent les memes. La menace reste toujours là, et ses consequences les plus negatives (parmis des autres, le virement des rançons et la liberation des prisonniers Jihadistes) restent aussi.

MOTS CLEFS : AQMI; Algérie; Ansaru; Boko Haram; enlevements; GSPC; In Amenas; Libye; Maghreb; Mali; MUJAO; Niger; Nigeria; raçons; Sahel; terrorisme djihadistesalafiste, Tunisie.

${ }^{3}$ Carlos Echeverría Jesús is Professor (Profesor Contratado Doctor) of International Relations at the Open University (UNED), in Madrid. He is Analyst of Jihadist-Salafist terrorism at the Grupo de Estudios Estratégicos (GEES), Spain, and Member of the Scientific Board of the African Journal for the Prevention and Combating of Terrorism of the ACSRT, African Union, Algiers. 


\section{INTRODUCTION}

This article is providing analysis related to the 'Al Qaida in the Lands of Islamic Maghreb' (AQIM) and the 'Movement for Oneness and Jihad in West Africa' (MUJAO, in its French acronym) strategies of kidnappings implemented in the Maghreb and in the Sahel. The scenario is including Mali and Niger, in the Sahel, and Algeria, Mauritania and Tunisia, in the Maghreb, but is also involving neighbouring countries, such as Nigeria or Cameroon. A number of references to the Nigerian Jihadist groups, Boko Haram and Ansaru, is obligged due to the increasing interaction among all these groups on the basis of the model provided by AQIM.

In recent years Jihadist Salafist groups acting in the area are more intent than ever to use kidnappings as a terrorist instrument. A huge region and the presence of Western citizens acting as aid workers, mining and oil companies' employees, or tourists, make virtually impossible to keep all these potential targets out of danger. Algeria is the key country, as the place where the Salafist Group for Preaching and Combat (GSPC, in its French acronym) inaugurated this practice in 2003.

Ten years after an initial massive kidnapping of 32 hostages, two terrorist groups AQIM and MUJAO - have in-herited the GSPC's activism in the area, both focusing in terrorist attacks and kidnapping for ransom activities. The latter continues remaining a threat with operations earning perpetrators between US\$50 million and US\$90 million in revenue in this period. ${ }^{4}$ Together with AQIM and MUJAO, other groups also acting in the region (mainly Boko Haram and Ansaru), are emerging as emulators.

\section{THE GSPC AND AQIM: THE CENTRAL ACTORS}

In April 2013, Mokhtar Belmokhtar, the mastermind behind the In Amenas hostage crisis in Algeria, was one of the leaders in the Algerian GSPC faction that took 32 European hostages in southern Algeria. After an Algerian military operation near Tamanrasset, 17 of the hostages were freed. The rest of the hostages were freed in northern Mali in August 2003, except for one German woman who died in the desert. A $\$ 5$ million euro ransom was paid. Ironically, the ransom mediator who was appointed by the Malian government was Iyad ag Ghali, the present leader of the AQIM-linked Ansar Eddine. ${ }^{5}$

In January 2007, the GSPC was renamed AQIM. One year later, the group began to conduct regular kidnappings. Since 2008, AQIM has regularly engaged in kidnapping

${ }^{4}$ See Algeria: In Amenas BP JV Wet Gas Facility Attack 16-20 January 2013, Unclassified OSINT V1.1.210113, p. 3, in <www.sevenquestions.co.uk>.

5 “'Happy End”, Jeune Afrique/l'Intelligent, Number 2224, August, 24-30, 2003, p. 15. 
operations in Mali and Niger in the Sahel as well as Tunisia, Algeria and Mauritania in the Maghreb. AQIM has earned millions of euros through ransoming Western hostages. More recently, it has begun to demand the release of jihadist prisoners as well. Northern Mali has been the core territory from where large-scale raids have been launched, as well as where militants have held hostages and negotiated ransoms. ${ }^{6}$

On February 22, 2008, AQIM kidnapped two Austrian tourists in southern Tunisia. In December 2008, it kidnapped two Canadian diplomats in northern Niger, including UN Special Envoy to Niger Robert Fowler. These kidnappings reflected both AQIM's regional connections and transnational ambitions. ${ }^{7}$

In January 2009, AQIM kidnapped four European tourists in Mali. In November 2009, it kidnapped three Spanish aid workers from Mauritania. ${ }^{8}$ The release of the Spanish aid workers was linked to a payment of 7 million euros, as well as Mauritania's extradition to Mali of Sid Ahmed Ould Hamma, who sentenced to a 12-year prison term in Nouakchott only two months prior. ${ }^{9}$ In the summer of 2011, Ould Hamma was linked to a Boko Haram incident in Nigeria.

On September 16, 2010, AQIM five French, one Togolese and one Malgache hostages at a uranium mine in Arlit, Niger. The two Africans and a Frenchwoman were released in February 2011. On November 20, a French national was kidnapped in Kayes, Mali. On January 7, 2011, AQIM kidnapped two French nationals in Niamey, Niger, and they were killed by AQIM the next day after French forces attempted to rescue them near the Malian border. ${ }^{10}$ On February 4, 2011, an Italian tourist and her Algerian driver were kidnapped in Djanet in southern Algeria, and freed on April 17, 2012. On September 24, 2011, two French nationals were kidnapped in Hombori, Mali, and in December five European tourists were kidnapped in Timbuktu, in which one German national was killed. ${ }^{11}$

This chronology is useful to provide a global vision of the transnational projection

\footnotetext{
${ }^{6}$ STEWART, S., “The Unspectacular, Unsophisticated Algerian Hostage Crisis”, Stratfor, January, 24, 2013, pages 1 and 2, in <www.stratfor.com>. Since 2008-2009 northern Mali has been central for AQIM in terms of terrorist financing issues and as a safe heaven in general. See US Department of State: Country Reports on Terrorism 2009. Mali, in <http://www.state.gov/s/ct/rls/crt/2009/140883.htm>.

7 See GUIDĖRE, M., La tentation internationale d'Al Qaïda au Maghreb, Paris-Brussels, IFRI\&Centre des Études de Sécurité, December 2008, p. 17.

${ }^{8}$ CEMBRERO, I., "El 'afable' terrorista y portavoz de Al Qaeda”, El País Digital, December 18, 2012, in $<$ www.elpais.es>.

${ }^{9}$ See "Recent Highlights in Terrorist Activity", CTC Sentinel, Vol. 3, Number 9, September 2010, p. 23, and ECHEVERRIA, C., "Yihadismo: escenarios africanos", Análisis del Grupo de Estudios Estratégicos (GEES), July 29, 2011, in <www.gees.org>.

${ }^{10}$ Belmokhtar was the responsible of this frustrated kidnapping. See "AQMI. Nigériens et français se concertent", Jeune Afrique, Number 2611, January, 23-29, 2011, p. 11.

${ }^{11}$ ECHEVERRIA, C., Sobre la necesidad de asegurar el Sahel, Análisis GEES, November 11, 2011, in <www. gees.org>.
} 
of the terrorists, their increasing use of violence, the focus on French nationals and interests, and finally the growing number of non-French nationals who have become victims.

Kidnapping Westerners in southern Tunisia, in Arlit, Niger, or in the most important road in Mauritania (that connecting Nouadhibu and Nouakchott), among other places, demonstrated the terrorists' ability to operate hundreds of kilometers from their core territory in northern Mali. AQIM's 'modus operandi' also indicates that terrorists prefer to kidnap more than one person because having multiple hostages allow them to kill one of them to make pressure for the ransom of the others. They also prefer to release women as soon as possible. Belmokhtar and Abdelhamid Abu Zeid-the first is suposed to have been killed in Mali and the death of the second was confirmed by France-have been the mean protagonists of these kidnappings. Abu Zeid was considered one of the most violent jihadist leaders in the region, linked to the executions of two European hostages, a British and a French, in 2009 and 2010.

The terrorists communicate mainly through 'Agence Nouakchott d' Information' and they use mediators in the ransom negotiations. One of them is Mustafa Ould Limam Chafi, who negotiated many of AQIM's hostage ransoms, including the release of Robert Fowler in 2008. Chafi and the Mauritanian news agency were also used by the group responsible for the May 2011 kidnappings in Nigeria - see below - suggesting that they had close ties with AQIM. This Mauritanian agency has also been used by the Belmokhtar's group during the January 2013 attack on the In Amenas plant. Belmokhtar has been waging for years an AQIM operative and, since October 2012, became the leader of its own group, named "Those Who Sign With Blood". ${ }^{12}$ In fact, discussions about the real loyalty of Belmokhtar, to AQIM or only to himself, are difficult to fully understand. Belmokhtar's group claimed responsibility for the In Amenas attack. ${ }^{13}$ The terrorists demanded since the beginning the end of the French operations in Mali and the release of more than 100 prisoners from Algerian prisons as well as Jihadist global leaders such as Aafia Siddiqui and Omar Abd Al Rahman. ${ }^{14}$

\section{MOVEMENT FOR ONENESS AND JIHAD IN WEST AFRICA (MUJAO) AND THE NIGERIANS BOKO HARAM AND ANSARU, AS AQIM'S EMULATORS}

MUJAO is an AQIM's splinter based in northern Mali that is believed to be mostly made up of non Algerian fighters (mainly Mauritanians and local Malians belonging

12 In October 2012, AQIM announced it had 'suspended' Belmokhtar from command.

${ }^{13}$ FISHER, M., "Looking for al-Qaeda in Algeria", WorldViews the Washington Post Foreign Staff, January 22, 2013, in <www.washingtonpost.com/blogs/views/wp/2013/01/22/looking-for-al-qaeda-in-algeria/>.

${ }^{14}$ Op cit. 
to the Songhai tribe). MUJAO paid attention to kidnapping for ransom practice since 2011, when the group was born. Then, MUJAO kidnapped three European aid workers in Tindouf, Algeria, on October 23, 2011. In April 2012 this group kidnapped seven Algerian diplomats at their Consulate in Gao, and one Portuguese in December also in northern Mali. ${ }^{15}$

Concerning the Algerian hostages, three were released and the Vice-Consul, Tahar Touati, was killed. In April 2013, three Algerian diplomats and the Portuguese remain in the hands of MUJAO. ${ }^{16}$ This group has focused its attacks on Algerian interests (two suicide attacks in the Algerian territory, in Tamanrasset and Ouargla, in 2012, and the kidnappings in Tindouf and Gao) but its projection is regional, acting in northern Mali, mainly in the Gao region.

MUJAO is not the only group that has emulated the AQIM's practice of kidnapping in the region. ${ }^{17}$ In May 2011, 'Al Qaida in the Lands Beyond the Sahel' claimed the kidnapping of a British and an Italian in the first kidnapping of Westerners in Nigeria. The terrorists sent a video in December 2011 and demanded 5 million of euros following the AQIM's strategy. The two hostages were killed by the terrorists in March 2012, in the context of a Nigerian \& British operation to release them. ${ }^{18}$ Also in Nigeria, on December 19, 2012 thirty members of Ansaru, a splinter group of Boko Haram that officially emerged in 2012 but is considered connected to the May 2011 kidnappings, attacked a 'Vergnet Co.' facility in Katsina, closed to the Niger border, and kidnapped a French engineer.

In the third week of February 2013, 14 foreign nationals were kidnapped in northern Nigeria and Cameroon in two separate actions. Seven workers of the Lebanese company "Setraco" were kidnapped in Jamare, northern state of Bauchi, Nigeria, and on March 11, Ansaru claimed their execution. ${ }^{19}$ Seven members of a French family were kidnapped by Boko Haram near the Nigerian border in Cameroon on February 19, 2013. ${ }^{20} \mathrm{Up}$ to this kidnapping, Boko Haram had only included Nigerian targets and acted only in

${ }^{15}$ See DENÉCÉ, E., Forces spéciales et groupes d'intervention antiterroristes algériens, Paris, Bulletin de Documentation Numèro 5 du Centre Français de Recherche sur le Renseignement Cf2R, January 2013, p. 7.

16 "Medelci à propos des otages algériens au Mali: "Pas de garantie qu' ils soient en vie", El Watan (Algeria), April 2, 2013, in <www.elwatan.com>.

17 See the list of foreigners kidnapped by AQIM and the MUJAO along 2012 in Alexander, Yonah, Terrorism in North Africa \& the Sahel in 2012, Arlington VA, Inter-University Center for Terrorism Studies-Potomac Institute for Policy Studies, February 2013, p. 27.

18 ORDAZ, P., "Italia pide explicaciones a Reino Unido por la muerte de un rehén en Nigeria", El País, March 10, 2012, p. 8.

${ }^{19}$ See "Nigeria: une video sur Internet affirme montrer les corps d'otages d'Ansaru", El Watan (Algeria), March, 11, 2013, in <www.elwatan.com>.

${ }^{20}$ CEMBRERO, I, "Un grupo radical rapta en Camerún a una familia con cuatro menores", El País, February 20, 2013, p. 8 . 
the Nigerian territory avoiding kidnappings. Once again, a chronology of kidnappings is useful in order to demonstrate than the 'AQIM model' is becoming central in the strategies of an increasing number of terrorist groups acting in the region.

MUJAO is defined as a split of AQIM, Ansaru as a split of Boko Haram, and the Belmokhtar group as a split of AQIM. In fact, interaction among them is frequent, provoking confusion among analysts and security officials. For instance, Mohamed Amine Bencheneb, who was killed by the Algerian forces in the In Amenas plant, was involved in the Tindouf kidnapping in October 2011 reflecting a connection between MUJAO and the Belmokhtar group splitted from AQIM in 2012. ${ }^{21}$

The kidnapping and killing of Western nationals by the four groups, and the MUJAO and Boko Haram kidnappings in Algeria and Cameroon are reflecting not only specialization but also a reinforcement of their trans-border ambitions. Ansaru had kidnapped foreigners, and is increasing its activities attacking nationals including military involved with the intervention in Mali. ${ }^{22}$

\section{CONCLUSIONS}

AQIM remains active and central in its criminal enterprise of kidnapping for ransom to finance their operations. The "Serval Operation" is seriously undermining the means of Jihadist-Salafist groups, but up to now it has not been able to release the hostages remaining in the hands of AQIM and MUJAO in Mali. One of the French hostages in the hands of AQIM, Philipe Verdon, who was kidnapped in northern Mali in September 2011, is even supposed to have been killed in March. ${ }^{23}$ Concerning Ansaru and Boko Haram, most recent kidnappings are significant shifts in these groups' targets and tactics.

Kipnappings before and after the French\&African military intervention in northern Mali are a dense web of overlapping, and sometimes contradictory, questions and mysteries about not only AQIM, MUJAO and the Nigerian Jihadist organizations as such groups, but also about particular individuals such as Belmokhtar, Abu Zeid, and others. The complexity of trying to understand the kidnapping strategies of them, and the connections among these groups, doesn't mean that there is no connection, but it does make it difficult to evaluate. The ability of these terrorist groups for keeping their hostages in the context of the military offensive initiated on January 11 indicates that the threat remains in the region.

\footnotetext{
${ }^{21}$ See Cf2R: "In Amenas, January 16, 2013, ouvert par la radio", Renseigneur Alerte, January 27, 2013, p. 2 , in $<$ http://twitter.com/renseignor $>$

${ }^{22}$ See BEY, M., TACK, S., "The Rise of a New Nigerian Militant Group”, Stratfor, February 21, 2013, in $<$ www.stratfor.com>.

23 “Mali: AQMI annonce l' exécution d' un otage français, Paris ne confirme pas", El Watan (Algeria), March 20. 2013, in <www.elwatan.com>.
} 


\section{PAIX ET SÉCURITÉ INTERNATIONALES}

REVUE MAROCCO-ESPAGNOLE DE DROIT INTERNATIONAL ET RELATIONES INTERNATIONALES

NOUVELLE ÉPOQUE

SUMARIE / Janvier - Décembre 2013 / N 1

\section{ÉDITORIAL}

Rachid el Houdaïgui, Alejandro del Valle Gálvez y Miguel Acosta Sánchez

\section{ÉTUDES}

José Manuel SOBRINO HEREDIA

La politique maritime integré de la UE et les bassins maritimes européens

Antonio BLANC ALTEMIR, Bénédicte REAL

Un nouevel élan dans les relations euro-méditerranéennes

Marcello DI FLLIPPO

Irregular Migration across the Mediterranean Sea: Problematic Issues Concerning the International Rules on

Safeguard of Life at Sea

\section{Zakaria ABOUDDAHAB}

La participation du Maroc au Partenariat de Deauville sur fond the transition dans les pays arabes

Irene FERNÁNDEZ MOLINA, Miguel HERNANDO DE LARRAMENDI

La construction de la interdépendance entre l'Espagne et le Maroc (1995-2009)

Victor L. GUTIIÉRREZ CASTILLO, Juan J. GARCÍA BLESA

Le Détroit de Gibraltar et l'application de la normative de l'Union Europeenne relativa aux énergies renovables

Mohamed ALI TOUZI

La vision de la Méditerranée depues les deux rives: una perpective a débatre

\section{NOTES}

Jean DUFOURCQ

Vers un espace stratégique euromahrébin

Nora SEDDEKI

Place du droit international dans le système juridique des Etats

Carlos ECHEVERRÍA JESÚS

Kidnappings as a terrorist instrument of AIQM and the MUJAO

Youssef EL HAMDOUNI

Internet y la Primavera Árabe: hacia una nueva percepción del ciberespacio

\section{DOCUMENTATION}

